\title{
Patognomonik CA 19-9 yüksekliğine sebep olan dalak kisti olgusu
}

\author{
Splenic cyst causing high levels of pathognomonic CA 19-9: A case report
}

\author{
Hüseyin DEMIRSOY ${ }^{1}$, Ahmet Tarık EMINLER², Metin ERCAN³ ${ }^{3}$ Mustafa İhsan USLAN², Aydın Şeref KÖKSAL², \\ Erkan PARLAK² \\ Özel Adatıp Hastanesi, ' Gastroenteroloji Kliniği, Sakarya \\ Sakarya Üniversitesi, Tıp Fakültesi, ${ }^{2}$ Gastroenteroloji Bilim Dalı, ${ }^{3}$ Gastroenteroloji Cerrahisi Bilim Dalı, Sakarya
}

\begin{abstract}
Kanser antijen 19-9 safra kanalı, kolon, mide, over, hepatosellüler, özofagus ve pankreas kanserleri gibi malign durumlarda yüksek seviyelerde görülebilen bir tümör göstergesidir. Pankreas kanseri ayırıcı tanısı ve yine pankreas kanserinde tedaviye cevap ve nüksün değerlendirilmesinde kullanılır. Yüksek seviyeler safra yolu obstrüksiyonu, kolanjit, inflamatuvar barsak hastalığı, akut veya kronik pankreatit, karaciğer sirozu, kistik fibrozis ve tiroid hastalıkları gibi benign durumlarda da görülebilir. Kanser antijen 19-9 yüksekliği ile birlikte olan nadir bir durum da dalak kistleridir. Olgumuz nadir olması ve Kanser antijen 19-9'un yayınlanılan benzer olgulardan yüksek seviyelerde olması sebebiyle sunulmuştur.
\end{abstract}

Anahtar kelimeler: CA 19-9, pankreas, splenik kist

\section{GiRis,}

Kanser antijen (CA) 19-9 safra kanalı, kolon, mide, over, hepatosellüler, özofagus ve pankreas kanserleri gibi malign durumlarda yüksek seviyelerde görülebilen bir tümör göstergesidir. Pankreas kanseri ile karışacak durumların ayırıc tanısı ve yine pankreas kanserinde tedaviye cevap ve nüksün değerlendirilmesinde kullanılır (1-3). Yüksek seviyeler safra yolu obstrüksiyonu, kolanjit, inflamatuvar barsak hastalığı, akut veya kronik pankreatit, karaciğer sirozu, kistik fibrozis ve tiroid hastalıkları gibi benign durumlarda da görülebilir (4). Nüfusun $\% 5^{\prime}$ inde vücudun CA 19-9 üretmediği bilinmektedir (5). Sağlıklı bireylerde de yüksek seviyeler görülebilmektedir (5).

Dalak kistleri nadir olmalarına rağmen, modern görüntüleme yöntemleri sayesinde sık tespit edilirler (6). Hastaların çoğunluğu 40 yaş altı ve kadındır.

Bu yazıda nadir bir birliktelik olması nedeniyle dalak kisti ile birlikte CA 19-9 yüksekliği olan bir hasta sunulmuştur.

\section{OLGU SUNUMU}

T.G., 47 yaşında kadın hasta; 2011'de sağ hipokondrium-
Cancer antigen 19-9 is a tumor marker present at high levels in the bile duct, colorectal, gastric, and hepatocellular cancer than esophagus or pancreas cancer. It is used to confirm the diagnosis of pancreas cancer, to assess the clinical response to the treatment, and to evaluate the recurrence of pancreatic cancer. High levels can also be seen in benign conditions, such as biliary tract obstruction, cholangitis, inflammatory bowel disease, acute or chronic pancreatitis, liver cirrhosis, cystic fibrosis, or thyroid diseases. Another rare condition which is associated with the high level of cancer antigen 19-9 is the splenic cyst. Hence, we are submitting this case report of splenic cyst because of its rareness and similarities to previously published cases with high levels of cancer antigen 19-9.

Key words: CA 19-9, pancreas, splenic cyst

da ağrı ve karında şişlik yakınması ile Genel Cerrahi polikliniğine başvuran hastada kolelitiazis ve dalakta bilgisayarlı tomografide (BT) $4 \mathrm{~cm}$ çapta kistik lezyon saptanmış. CA 19-9 düzeyi 93,8 U/ml (normal: 0-37) bulunan ve Ekinokok hemaglütinasyon testi negatif olan hasta Gastroenteroloji polikliniğine yönlendirilmiş.

Tahammül edilebilen karın ağrısı olan hastanın kontrol CA 19-9 düzeyi 98,78 U/ml (normal: 0-37) idi. Takibe allnan hastada karın ağrısı ısrarcı olunca üst batın magnetik rezonans (MR), magnetik rezonans kolanjiyopankreatografi (MRCP), kolonoskopi ve gastroskopi ile ileri tetkiki yapıldı. Sonuçları kolelitiazisi ve dalakta tespit edilen kisti dışında normal idi (Resim 1). Bu bulgularla CA 19-9 yüksekliği öncelikle kolelitiazise bağlandı. Ara ara ağrısı olan hastanın 3 ayda bir yapılan kontrollerinde CA 19-9'daki yükseklik 1 yıl kadar, aynı değerde sebat etti. CA 19-9 değeri Nisan 2012'de 128,07 U/ml ve Kasım 2012'de 114,11 idi. Hastanın safra kese operasyonu planlandı, öncesinde endosonografisi yapıldı. Endosonografide pankreas ve safra yolları normal bulundu. Hasta Mart 2013'de safra kesesi operasyonu geçirdi. Ancak postope- iletişim: Birol BOSTANCI
Özel Adatıp Hastanesi, Gastroenteroloji Bölümü,
Adapazarı Sakarya
Tel: +90 2648881999 • E-mail: ebbostanci@yahoo.com
Geliş Tarihi: 08.10.2015 • Kabul Tarihi: 30.09.2017 
ratif takipte sağ hipokondriumdaki ağrısının ve CA 19-9 yüksekliğinin değişmediği görüldü. Aralık 2013'de CA 19-9 değeri 119,19 U/ml olan hastanın 2014 yılında yapılan tetkiklerindeki değerlerinde tedrici artışlar meydana geldi. Aralık 2014'de CA $19-9$ değeri $274 \mathrm{U} / \mathrm{ml}$ idi. Mart 2015'de yapılan kontrolünde CA 19-9 > $1200 \mathrm{U} / \mathrm{ml}$ olarak saptandı. Patognomonik yükseklik saptandığı için MR ve MRCP'si tekrarlandı. Dalaktaki kistik lezyonların büyüdüğü ve sayıca arttığı görüldü (Resim 2). Endosonografi tekrarlandı. Pankreas ve safra yolları yine normal idi. Cerrahi ile ortak yapılan değerlendirme sonrası splenektomi kararı verildi. Hasta Mart 2015'de splenektomi ameliyatı

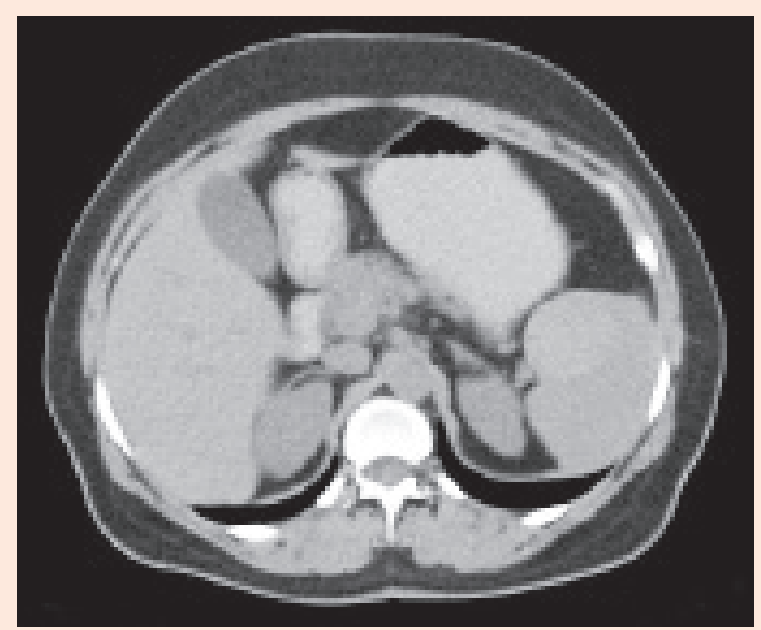

Resim 1. CA 19-9 yüksekliği olan hastada dalak kistleri izleniyor geçirdi. Ameliyatı takiben CA 19-9 değeri normal sınırlarına döndü (CA 19-9. 31,14) ve hastanın ağrıları azaldı. Patolojik muayene sonucu benign splenik kist şeklinde idi.

\section{TARTIŞIMA}

CA 19-9 özellikle tükrük bezleri, biliyer epitel, pankreatik duktal epitel ve metaplastik mezotelyal epiteli gibi glandüler epitel hücrelerinde bulunan bir glikoproteindir (1). Pankreas adenokarsinomu için önemli bir gösterge olan CA 19-9, pankreasın hem normal hem de tümör içeren epitel hücrelerinden kaynaklanabilir. Pankreas kanseri ile karışacak hastalıkların ayıııı tanısı ve yine pankreas kanserinde tedaviye cevap ve nüksün değerlendirilmesinde kullanılır $(2,6)$. Pankreas kanserleri dışında, safra kanalı, kolon, mide, over, hepaosellüler ve özofagus kanserleri gibi malign durumlarda da yüksek seviyelerde görülebilen bir tümör göstergesidir. Yüksek CA 19-9 (>1.000 U/ml) seviyeleri preoperatif inoperabilite kriteri olarak kabul etmek için yeterli olmasa bile çoğu zaman rezeksiyon şansı olmayan ileri tümörü işaret eder (7). Postoperatif CA 19-9 seviyesinde düşme ise iyi sürvi ile koroledir. Tersine postoperatif yüksek seviyeler de kısa sürvi ve hastalığın nüks oranının yüksekliği ile koroledir. Yüksek seviyeler safra yolu obstrüksiyonu, kolanjit, inflamatuvar barsak hastaığı, akut veya kronik pankreatit, karaciğer sirozu, kistik fibrozis ve tiroid hastalıkları gibi benign durumlarda da görülebilir (7). Sağlıkı bireylerde de yüksek seviyeler görülebilmektedir. Ayrıca genel nüfusun $\% 5$ 'inde vücudun CA 19-9 üretmediği bilinmektedir (5).
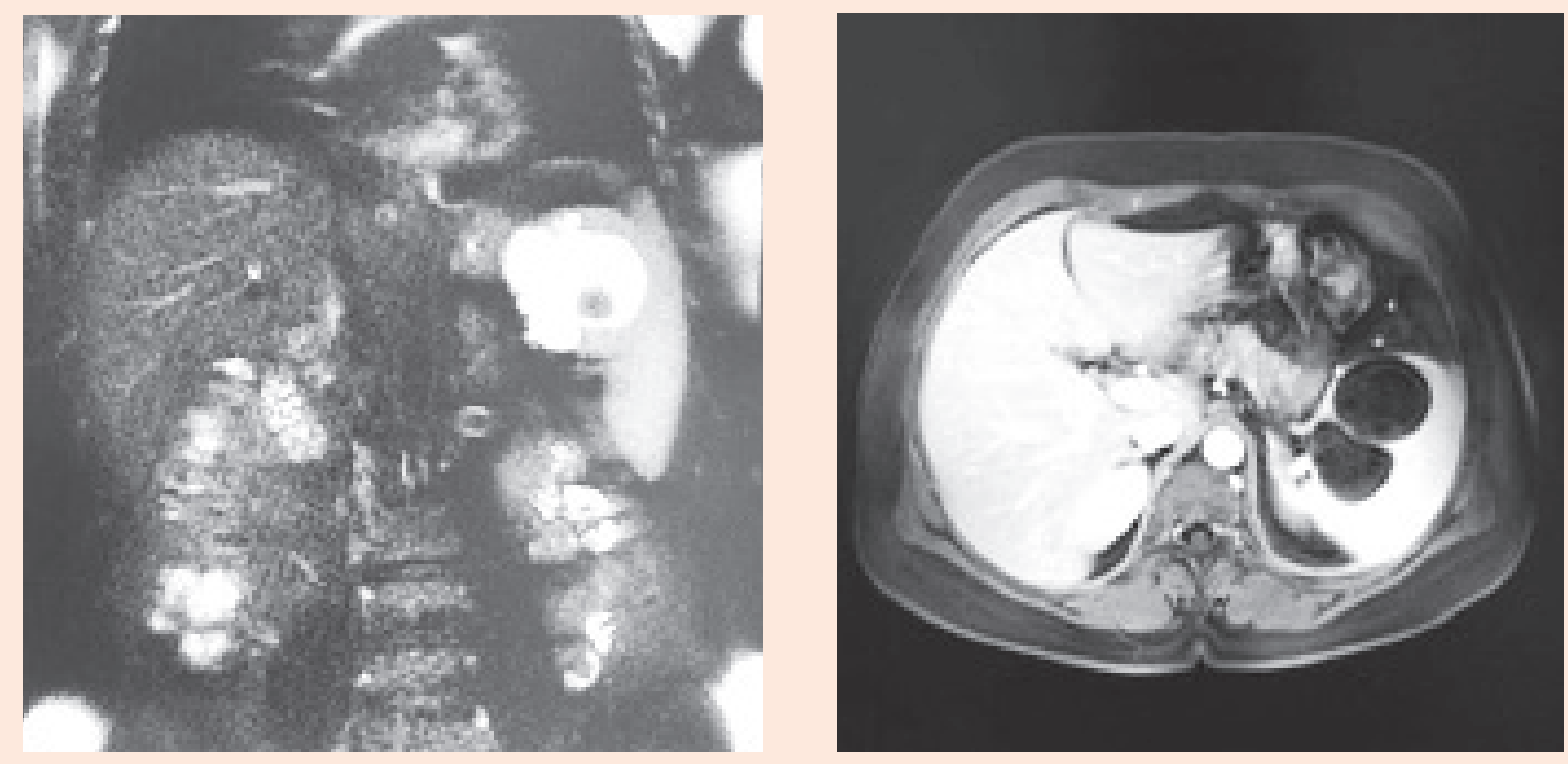

Resim 2. CA 19-9 düzeyinde artma ile birlikte dalaktaki kistlerin boyut ve sayısında artış izleniyor. 
Dalak kistlerinin CA 19-9’u yükseltiğini ilk Terada ve arkadaşları 1994'de rapor etmişlerdir (8). Daha sonra çoğunluğu epitelyal orijinli olmak üzere 30'u aşkın CA 19-9 yüksekliği ile giden dalak kisti rapor edilmiştir $(9,10)$.

Dalağın malign kistik lezyonları çok nadir görülür. Dalak kistlerinin çoğunluğu benigndir. Dalak kistleri parazitik ve nonparazitik kökenli olmak üzere iki grup halinde sınıflandırılır. Dalak kistlerinin 2/3'ü parazitikdir. Ve parazitik olan kistlerin çoğunluğu Ekinokokus granulususa bağlıdır (11). Nonparazitik olan splenik kistler epitel hücresinden oluşmuş bir kılıf içerip içermemelerine göre gerçek (\%90'ı) ve psödokist olmak üzere ikiye ayrılırlar (12). Gerçek kistlerin çoğu orijin olarak epitelyal kökenlidir. $5 \mathrm{~cm}$ 'den büyük ve küçük oluşlarına göre büyük ve küçük kist olarak ayrılırlar.

Hasta sağ hipokondriumdaki künt ağrısı sebebiyle başvurduğu Cerrahi polikliniğinden, saptanan kolelitiazis ve dalak kistlerinin yanında CA 19-9 değeri yüksek bulunduğu için bize yönlendirilmişti. Dalak kistinin etiyolojisine yönelik yapılan Ekinokok hemaglütinasyon tesi negatif idi, dalak kisti nonparazitik kist olarak değerlendirildi. Mevcut bulgularla CA 19-9'un iki kat yüksekliğinin sebebi, bilinen bir yükseklik sebebi olan, kolelitiazis olarak düşünüldü. Yakınması ısrarcı olduğu için MR, MRCP, kolonoskopi ve gastroskopi ile ileri tetkiki yapıldı. Dalak kisti ve kolelitiazisi dışında hç bir patolojik bulgu saptanmadı. Ağrı ve CA 19-9 yüksekliğine kolelitiazis'in sebep olduğu düşünüle- rek, hastaya laporoskopik kolesistektomi operasyonu yapıldı. Takibinde kolesistektomiye rağmen yüksek CA 19-9 değerinin düşmediği ve tedrici olarak arttığı görüldü. Tahammül edilebilir düzeyde olan karın ağrısı ameliyat sonrası hiç azalmadan devam etti. CA 19-9'daki tedrici yükselme sürekli olarak devam etti ve nihayetinde CA 19-9 değerinin 1.200'ün üzerine çıktığı görüldü. Bu durum malign hastalıklar yönünden tekrar ayırıcı tanı yapmamızı gerektirdi. Üst batın dinamik MR, MRCP ve endosonografi ile pankreas ve safra yolu malignitelerine yönelik ileri incelemesi yapıldı. Yapılan incelemelerde dalaktaki kistlerin arttığı ve çaplarının biraz büyüdüğü görüldü (Resim 2). Literatürde dalak kistlerinin nadir de olsa CA 19-9'u yükselttiğine dair yayınlar olması ve hastamızdaki dalak kistlerinin büyümesi ve sayısının artması sebebiyle cerrahi tedavi seçenek olarak ortaya çıktı. Hasta cerrahi konseyde değerlendirildi ve tartışıldı. Splenektomi kararı verildi. Çıkarılan kistlerin patolojik inceleme sonucu benign splenik kist şeklinde idi.

Operasyon sonrası yapılan tetkiklerde CA 19-9 değerinin normal sınırlara düştüğü görüldü. Bu durumda olgumuzda CA 19-9 yüksekliğinin sebebi dalak kistlerine bağlanıldı. Nadir bir sebep olması ve diğer rapor edilen olguların büyük çoğunluğundan farklı olarak CA 19-9 değerinin çok yüksek seviyelerde bulunması sebebiyle rapor edilmesine karar verildi.

\section{KAYNAKLAR}

1. Steinberg W. The clinical utility of the CA 19-9 tumor-associated antigen. Am J Gastroenterol 1990;85:350-5.

2. Goonetilleke KS, Siriwardena AK. Systematic review of carbohydrate antigen (CA 19-9) as a biochemical marker in the diagnosis of pancreatic cancer Eur J Surg Oncol 2007;33:266-70.

3. Boone BA, Steve J, Zenati MS, et al. Serum CA 19-9 response to neoadjuvant therapy is associated with outcome in pancreatic adenocarcinoma. Ann Surg Oncol 2014;21:4351-8.

4. Ito S, Gejyo F. Elevation of serum CA19-9 levels in benign diseases. Intern Med 1999;38:840-1.

5. Tempero MA, Uchida E, Takasaki H, et al. Relationship of carbohydrate antigen 19-9 and Lewis antigens in pancreatic cancer. Cancer Res 1987;47:5501-3.

6. Matsumoto S, Mori T, Miyoshi J, et al. Huge splenic epidermoid cyst with elevation of serum CA19-9 level. J Med Invest 2015;62: 89-92.

7. Goonetilleke KS, Siriwardena AK. Systematic review of carbohydrate antigen (CA 19-9) as a biochemical marker in the diagnosis of pancreatic cancer. Eur J Surg Oncol 2007;33:266-70.

8. Terada T, Yasoshima M, Yoshimitsu Y, Nakanuma Y. Carbohydrate antigen 19-9 producing giant epithelial cyst of the spleen in a young woman. J Clin Gastroenterol 1994;18:57-61.

9. Urban D, Catane R. Serum tumor markers in oncology. IMAJ Isr Med Assoc J 2009;11:103-4.

10. Brauner $E$, Person B, Ben-Ishay $O$, Kluger $Y$. Huge splenic cyst with high level of CA 19 -9: the rule or the exception? Isr Med Assoc J 2012;14:710-1.

11. Hansen MB, Moller AC. Splenic cysts. Surg Laparosc Endosc Percutan Tech 2004;14:316-22.

12. van Lacum MW, Hessels RA, Kremer GD, Jaspers CA. A splenic cyst and a high serum CA 19-9: a case report. Eur J Intern Med 2000;11:104-7. 